ワークショップ 3

WS3-1

骨関節破壊のイメージング

\title{
菊田順一
}

\section{(大阪大学大学院医学系研究科 免疫細胞生物学)}

関節リウマチ（RA）は，炎症滑膜の増殖と進行性の骨破壊を伴う自己免疫疾患である。また，RA 患者の多くは，炎症，加齢，閉経，ステロイド薬など様々な原因で骨粗鬆症を合併する。 RAにおける 骨破壞と骨粗鬆症における骨密度の低下は，いずれも破骨細胞の機能立進が関与する病態である。そ のため, RA を治療するうえで, 破骨細胞の機能をいかに制御するかということが大変重要となる.

石灰質に囲まれた骨組織は，生体で最も硬い組織であるため，従来，生きたままでの観察が極めて 困難であると考えられていたが，本演者らは，二光子励起顕微鏡を駆使して，個体を“生きたまま” で観察することにより，生体骨・関節組織内における“生きた”細胞動態を解析するライブイメージ ング系を確立した。本技術を用いて，骨表面上での“生きた”破骨細胞による骨破壊過程をリアルタ イムで可視化することに成功し, 破骨細胞による骨吸収制御メカニズムを解明するとともに, 生体内 において各種骨粗鬆症治療薬および生物学的製剤が破骨細胞に及ぼす効果を明らかにした。さらに最 近，ライブイメージング技術を用いて，骨芽細胞と破骨細胞のクロストークの可視化とその動態解析 にも取り組んでいる.

本講演では，これらの研究成果について，最新のイメージング画像とともに紹介する. 